\title{
Philodendron williamsii Hook. f. (Araceae), an endemic and vulnerable species of southern Bahia, Brazil used for local population
}

\author{
Luana S.B. Calazans ${ }^{1}$, Erica B. Morais ${ }^{2} \&$ Cassia M. Sakuragui ${ }^{3}$ \\ 1,3 Universidade Federal do Rio de Janeiro, CCS, Instituto de Biologia, Departamento de Botânica, Av. Carlos Chagas Filho, 373 - \\ Sala A1-084 - Bloco A, CEP 21941-902, Ilha do Fundão, Rio de Janeiro, RJ, Brazil \\ ${ }^{2}$ Universidade Federal do Rio de Janeiro, Museu Nacional, Departamento de Botânica, Quinta da Boa Vista, CEP 20940-040, Rio \\ de Janeiro, RJ, Brazil \\ Emails: ${ }^{1}$ luanasbcalazans@gmail.com (corresponding author), ${ }^{2}$ ericcabarroso@gmail.com, ${ }^{3} \mathrm{cmsakura12@gmail.com}$
}

\begin{abstract}
An updated description and information on ecology geographical distribution, ethnobiology, uses and conservation of Philodendron williamsii are presented here. The species has a restricted geographical distribution and the roots of its natural populations are widely extracted to be used for local handicraft. During the fertile period of the plant, areas where the species grow were prospected in order to collect, observe, photograph and consult people who directly use parts of the plants. Additional specimens from five herbaria were analyzed. We propose the inclusion of the species as Vulnerable based on the categories and the criteria proposed by the IUCN. Environmental education for the local extractors and the regularization of its extractive activity are suggested here.
\end{abstract}

Keywords: Conservation, extractivism, imbé, southern Bahia, taxonomy.

Date of publication (online): 26 December 2012

Date of publication (print): 26 December 2012

ISSN 0974-7907 (online) | 0974-7893 (print)

Editor: Anonymity requested

Manuscript details:

Ms \# 03124

Received 16 March 2012

Final received 01 September 2012

Finally accepted 24 November 2012

Citation: Calazans, L.S.B., E.B. Morais \& C.M. Sakuragui (2012) Philodendron williamsii Hook. f. (Araceae), an endemic and vulnerable species of southern Bahia, Brazil used for local population. Journal of Threatened Taxa 4(15): 3390-3394.

Copyright: (C) Luana S.B. Calazans, Erica B. Morais \& Cassia M. Sakuragui 2012. Creative Commons Attribution 3.0 Unported License. JoTT allows unrestricted use of this article in any medium for non-profit purposes, reproduction and distribution by providing adequate credit to the authors and the source of publication.

Acknowledgements: We are grateful to Marco Octávio Pellegrini for the help with the images and suggestions in the manuscript, Rodrigo Theófilo Valadares for the map elaboration, the craftsmen and foresters Mr. Aderval and Mr. Gildo for the field assistance, all the people who helped us with information, Hugo Fernandes-Ferreira for the help with the ethnobiology methodology, Vitor Tenorio da Rosa for the contribution with anatomical knowledge and Ana Cecília Castro for suggestions in the manuscript.

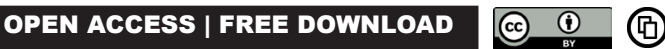

Resumo (Portuguese Abstract): São aqui apresentadas uma descrição atualizada, informações sobre a ecologia, distribuição geográfica, etnobiologia, usos e conservação de Philodendron williamsii. A espécie tem distribuição geográfica restrita e as raízes de suas populações naturais sofrem intenso extrativismo voltado para o artesanato local. Áreas do habitat natural da espécie foram visitadas durante seu período fértil com o objetivo de coletar, observar, fotografar e consultar a população local que faz uso direto da planta. Espécimes adicionais de cinco herbários foram também analisados. A inclusão da espécie na Lista Vermelha de Espécies Ameaçadas é proposta com base nas categorias e critérios da IUCN. Sugerimos a educação ambiental com os extratores locais e a regularização desta atividade para conservação da espécie.

Palavras chave: conservação, extrativismo, imbé, Sul da Bahia, taxonomia.

Philodendron williamsii Hook. f. is a poorly known species of Philodendron subgenus Meconostigma (Araceae), described in 1871 from material collected by C.H. Williams in the Bahia State, probably near Salvador and has been cultivated at Kew (Mayo 1991).

Due to some similar morphological characters with P. stenolobum E.G. Gonç. (Gonçalves \& Salviani 2002), many horticulturists believe they have it in their collections, however, they actually possess specimens of the latter. Populations currently circumscribed as $P$. stenolobum, which is endemic to the Espírito Santo state, were treated as $P$. williamsii in the latest revision of the subgenus Meconostigma (Mayo 1991), since the author could not have access to the fertile material from these populations. The main differences between them lie in leaf dimensions and gynoecium morphology (Table 1 in Gonçalves \& Salviani 2002). Despite its ornamental potential for landscaping, $P$. williamsii is rarely found in live collections due to the difficulty of its propagation and cultivation.

The aim of the work is to give new information on 
ecology, geographical distribution, uses, ethnobiology and conservation of $P$. williamsii, an endemic and threatened species from the Atlantic Forests of southern Bahia.

\section{Materials and Methods}

Field work was carried out in February and December of 2011, searching for Philodendron species in Bahia State, specially prospecting areas of Itacaré and Una, where the species grows. Special effort was made to collect the plants during the fertile period. In order to obtain information on its use by the local population, semi-structured interviews were conducted (Huntington 2000), selecting informants (craftsmen, merchants and foresters) who use parts of the plants directly in their activities.

To complement the description, ecological data and geographical distribution, material from the following herbaria were also analyzed: ALCB, CEPEC, HUEFS, RB, RFA (acronyms according to Thiers, constantly updated). The descriptions followed Mayo (1991), with modifications. The conservation status was proposed based on the categories and the criteria proposed by the IUCN (2010).

\section{Results and Discussion}

Philodendron williamsii Hook. f., Bot. Mag. 97: t. 5899. 1871. Type: near Salvador, Bahia, Brazil, Nov. 1878, C.H. Williams s/n (holotype K, image!).

Hemi-epiphyte, terrestrial or rupicolous herb, arborescent, internodes less than $1 \mathrm{~mm}$ long; intravaginal squamules numerous, $1-2.5 \mathrm{~mm}$ long or less, ca. 1-2 mm broad, triangular or multi-toothed, inconspicuous, detachable, persistent or deciduous.

Leaf: Petiole $30-82 \mathrm{~cm}$ long, broadly canaliculate with acute margins, blade with anterior and posterior division, overall length $32-100 \mathrm{~cm}$, overall width 21.4-50 cm, ovate to elongate-ovate, margin entire to repand, subcoriaceous to coriaceous, dark glossy green above, paler green below, apex acute to obtuse with acuminate tip, base sagitatte, anterior division $21.6-70 \mathrm{~cm}$ long, primary lateral veins $4-5$ per side, prominent on abaxial surface, paler green above, redtinged below, secondary lateral veins evident, posterior divisions 7.7-25.3 cm long, basal ribs denuded for $3.3-5.9 \mathrm{~cm}$.

Inflorescence: One per floral sympodium; peduncle $6.5-10.8 \mathrm{~cm}$; spathe $15.3-30 \mathrm{~cm}$, cymbiform, median constriction absent, externally green and internally cream; spadix $16-29.5 \mathrm{~cm}$ long, male zone 3.5-7.5 cm, sterile median zone $4-14.5 \mathrm{~cm}$, female zone $3,6-8.5 \mathrm{~cm}$.

Gynoecium:ovaryflask-shaped,(10)-11-13-locular, locules 3-4-ovulate, axial placentation, style lobes very elongated, style body lacking, central dome present, short.

Examined Material: Brazil. Bahia: Cairú, Garapuá, caminho para a Mata do Abreu, 12.iv.2003, coll. M.L. Guedes \& D. Rigueira 10247 (ALCB); same city, ramal para os povoados de Torrinha e Tapuía, 25.x.1984, coll. L.A. Mattos Silva \& T.S. dos Santos 1772 (CEPEC); Ilhéus, Km 35 da estrada Ilhéus Serra Grande, 22.x.1983, coll. A.M. Carvalho et al. (CEPEC 33176); Itacaré, Caminho entre as praias da Concha e de Rezende, $14^{0} 16^{\prime} 37.0^{\prime \prime}$ 'S \& 38 59'03.7' W, 16.ii.2011, coll. L.S.B. Calazans \& E.B. Morais 54 (HUEFS); same locality, 14.xii.2011, coll. L.S.B. Calazans et al. 155 (RFA); same city, 2-3 km ao sul da cidade, perto da foz do riacho ao lado de algumas barracas, 25.v.1991, coll. S.J. Mayo et al. 771 (CEPEC, RB); same locality, 28.iv.1991, coll. S.J. Mayo 765 (CEPEC, RB); Maraú, 5km SE of Maraú at junction with road North to Ponta do Mutá, $14^{\circ} 08^{\prime} \mathrm{S}$, 3900' W, 2.ii.1977, coll. Harley et al. 18501 (CEPEC, $\mathrm{RB}$ ); Olivença, $6 \mathrm{~km}$ a leste da cidade, $14^{0} 58^{\prime} 15.2^{\prime \prime S}$ \& 3902'11.9”'W, 29.ii.2000, coll. E.G. Gonçalves et al. 411 (CEPEC); Una, Reserva Biológica do Mico-

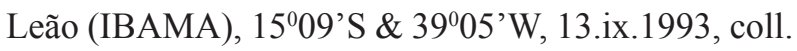
A.M. Amorim et al. 1337 (CEPEC); same locality, 20.ix.1998, coll. S.C. Sant'Ana et al. 674 (CEPEC); same city, road to Ilhéus, $13 \mathrm{~km}, 15^{\circ} 13^{\prime} \mathrm{S} \& 39^{\circ} 04^{\prime} \mathrm{W}$, 23.i.1977, coll. R.M. Harley 18187 (CEPEC); same city, Reserva Biológica de Una, $15^{\circ} 10.938^{\prime} \mathrm{S}$ \& $39^{\circ} 04.181^{\prime} \mathrm{W}, 11 . x i i .2011$, coll. L.S.B. Calazans et al. 139 (CEPEC); Uruçuca, Parque Estadual Serra do Condurú, 14028'803"S \& 3906’344”W, 28.ix.2000, coll. W.W. Thomas et al. (CEPEC 86775); same city, Serra Grande, $14^{0} 25^{\prime} \mathrm{S} \& 39^{\circ} 01^{\prime} \mathrm{W}$, same data, coll. A.M. Amorim et al. 641 (CEPEC); same locality, 06.iii.2001, coll. E.G. Gonçalves et al. 789 (CEPEC); Valença, RPPN Fazenda Água Branca, 13ำ19'44"S \& 3905'25”'W, 30.x.2004, coll. P. Fiaschi et al. 2618 (CEPEC).

\section{Ecology and Distribution}

Philodendron williamsii has a distribution restricted 


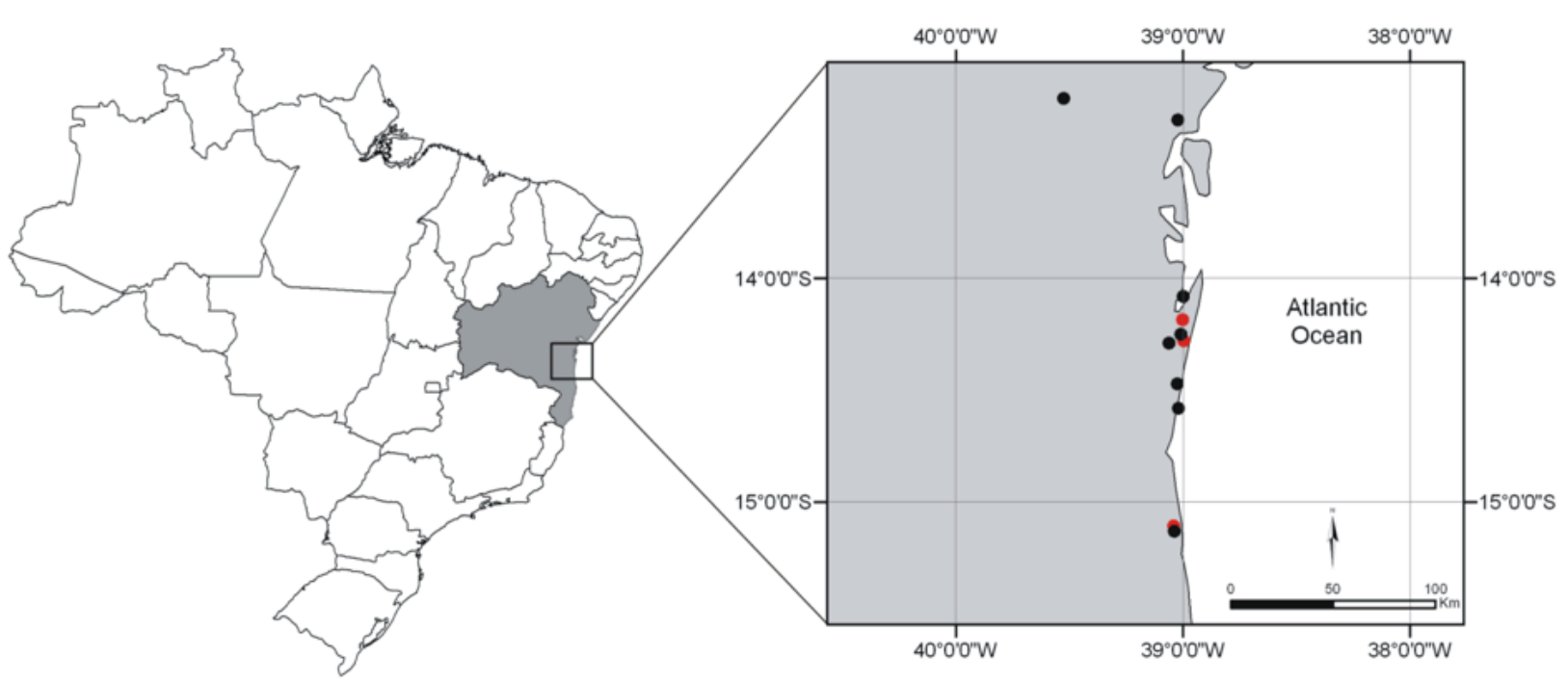

Figure 1. Geographic distribution of Philodendron williamsii. Red points are our collections (Calazans \& Morais 54 and Calazans et al. 139,155$)$ and black points are other collections from the analyzed Herbaria.

to the Atlantic Forest on the southern coast of the Brazilian state of Bahia, where part of the original vegetation remains protected due to ecotourism (Oliveira 2002) and cocoa cultivation, which is the major crop of the region (Cassano et al. 2009; CEPLAC 2011). Although its type locality is pointed probably near Salvador, there are no records for the region and vicinity and we did not see any population around the city. This species can be considered rare in nature since there are few herbarium collections and a limited area of occurrence (Fig. 1).

It occurs in the restingas and pluvial forest, including flooded areas, as hemi-epiphytes, rupicolous or terrestrial. Generally, populations are not too close. They were always under median to high luminosity, as commonly noted in the Philodendron subg. Meconostigma. Terrestrial individuals are generally found in forest edges, clearings or sandy soils of restinga vegetation. Hemi-epiphytes are more common and can reach a great height in the canopy (up to $25 \mathrm{~m}$ ), where the light intensity is higher. This feature makes these hemi-epiphytes individuals hard to be noticed and collected, as reported by many collectors. However, once found, it can be promptly recognized by the long feeder roots that reach the ground, sometimes growing several meters until finally entering the soil (Image 2b).

There is a remarkable population growing on granitic outcrops rocks at Itacaré beach, a few meters from the sea (Image 1a\&d). This same population
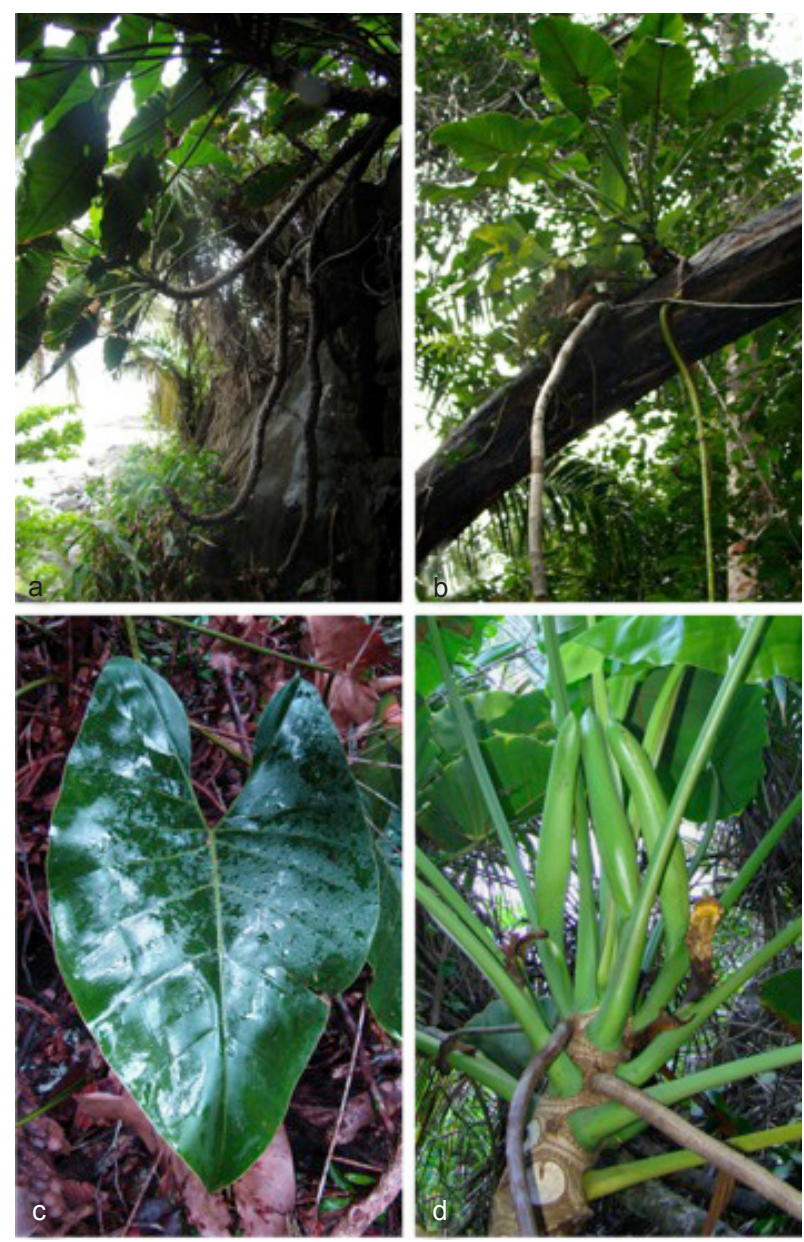

Image 1. Philodendron williamsii Hook $f$.

a - Rupiculous population (Calazans \& Morais 54); b -

Hemi-epiphyte individual with storied cork recently taken (Itacaré, not collected); c - Leaf blade (Calazans et al.

139); $d$ - Inflorescence in full bloom. (Calazans et al. 155). Photos: LSB Calazans \& EB Morais. 

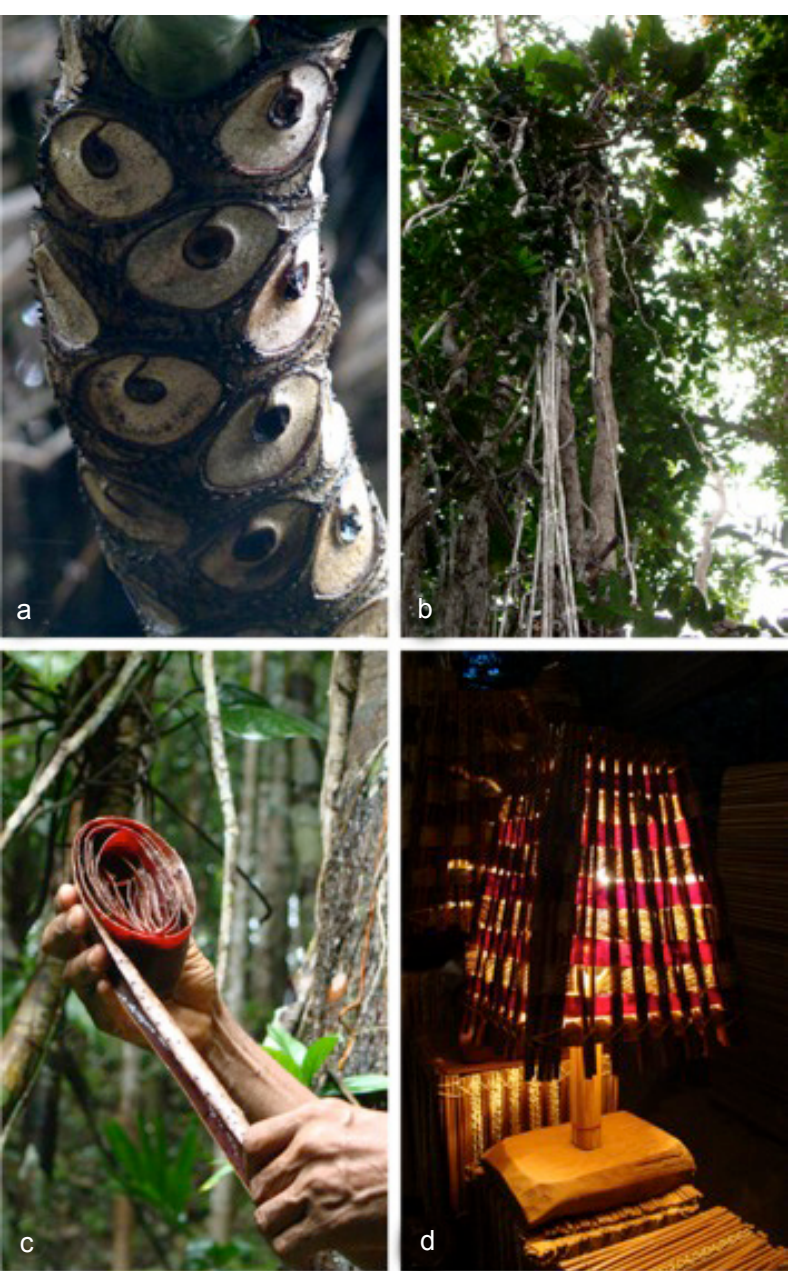

Image 2. Philodendron williamsii Hook f.

a - Stem (Calazans \& Morais 54); b - Feeder roots (Una, not collected); c - Storied cork recently extracted from the roots; $d$ - Handcraft lampshade made from the storied cork. Photos: LSB Calazans \& EB Morais.

was previously related as a form of $P$. corcovadense Kunth with shorter internodes (Mayo 1991), but we were able to collect their flowers and fruits and verify they belong to $P$. williamsii. These species are morphologically similar and frequently grow in similar conditions, both being endemic to the Brazilian Atlantic coast. The main differences between them are in stem and gynoecium morphology (longer internodes, conspicuous intravaginal squamules, ovary barrel-shaped, 4-8-locules and style lobes short in $P$. corcovadense).

\section{Uses and Ethnobiology}

Mayo (1991) reported that $P$. williamsii fruits were appreciated as a native delicacy, called "milho de caboclo" (caboclo's corn), but despite our efforts, we couldn't confirm if this use by the local population still occurs.

The roots are widely used in local craftwork. The handicraftsmen refer to the young roots of $P$. williamsii as "imbé" and take the outer layer (storied cork) (Image 2c) to ornament their pieces, such as lampshades, luminaries and trays (Image 2d). These layers are very slender and translucid, allowing the passage of red-colored light, which adds a special beauty to the pieces, making it unique and characteristic of this area in Bahia. The mature roots are grey and opaque but possess some brightness and are also used to make handcrafted, rustic pieces.

The entire plant is called "mãe do imbé" (imbé's mother) and the leaf scars in the stem are called "olhos do imbé" (imbé's eyes) (Image 2a) due to its appearance. The craftsmen are easily able to distinguish the Philodendron species that occur in the region, almost entirely, based on their use. Thus, $P$. fragrantissimum (Hook) G. Don., a common species in the region, is called "mother", but is a mother that never gives "imbé". Philodendron pedatum (Hook.) Kunth and P. hederaceum (Jacq.) Schott are not recognized as "mothers", probably because their morphology differs from much of $P$. williamsii.

Another folk belief is that $P$. williamsii plants are always born on the tree branches and when the "mother" is mature, the "imbé" (roots) drop to the ground. This may be partly explained due to the difficulty to find young terrestrial individuals, probably due to light conditions on forest soil.

Although the craftsmen who accompanied us said that only few roots are taken off each individual, this activity must be carefully monitored since it is very common in southern Bahia and puts these populations at risk. The local population knows by tradition that just after a year the roots are ready again to be extracted, but they are not aware that the plant might die if the roots are completely removed. This shows that tradition and popular knowledge doesn't always assure the protection of this species.

The roots of two others Philodendron subg. Meconostigma species that occur in the Atlantic Forest, P. bipinnatifidum Schott ex Endl. and P. corcovadense, respectively in São Paulo and Paraná states, are also used by the local population to create craft items and other rural constructions (Schneider \& Mello Filho 2001; Valente \& Negrelle 2011). In the Amazonian region, various species of the genus Heteropsis Kunth 
are also used for this purpose (Soares et al. 2011).

\section{Conservation}

In view of its rarity and anthropic pressure, we propose the species be assessed for inclusion in the IUCN Red List of Threatened Species providing support for its conservation. We believe that the regularization of extractive activity and environmental education is important and will allow the continued use of $P$. williamsii in craftwork without affecting their natural populations. This species is known only in a small area in southern Bahia $\left(<20000 \mathrm{~km}^{2}\right)$, mainly in the moist forests, occurring at least in three conservation units, with very few known populations.

Due to its ecological features and ethnobiology, this plant has become increasingly difficult to find in the past few years. To help assure the continuation of this traditional activity, studies on its propagation in vitro and acclimatization would also be desired.

\section{REFERENCES}

Cassano, C., G. Schroth, D. Faria, J. Delabie \& L. Bede (2009). Landscape and farm scale management to enhance biodiversity conservation in the cocoa producing region of southern Bahia, Brazil. Biodiversity and Conservation 18: 577-603.

CEPLAC (Comissão Executiva do Plano da Lavoura Cacaueira) (2011). Cacau - Informações de
Mercado (19/09/2011 à 16/12/2011). Ano III, no. 13. $<$ http://www.ceplac.gov.br/paginas/infomercado/ informa $\%$ C3\%A7\%C3\%B5es\%20de20mercado\%2013. pdf $>$ Downloaded on 24 February 2012.

Gonçalves, E.G. \& E.R. Salviani (2002). New species and changing concepts of Philodendron subgenus Meconostigma. Aroideana 25: 3-15.

Huntington, H.P. (2000). Using traditional ecological knowledge in science: methods and applications. Ecological Applications 10: 1270-1274.

Mayo, S.J. (1991). A revision of Philodendron subgenus Meconostigma (Araceae). Kew Bulletin 46: 601-681.

Oliveira, J.A.P. (2002). Implementing Environmental Policies in Developing Countries Through Decentralization: The Case of Protected Areas in Bahia, Brazil. World Development 30(10): 1713-1736.

Schneider, S.M. \& L.E.M. Filho (2001). Duas espéices ornamentais de Philodendron Schott (subgênero Meconostigma) das restingas fluminenses. Boletim do Museu Nacional, Nova Série, Botânica 114: 1-15.

Soares, M.L.C., S.J. Mayo, R. Gribel \& D. Kirkup (2011). Elliptic Fourier Analysis of leaf outlines in five species of Heteropsis (Araceae) from the Reserva Florestal Adolpho Ducke, Manaus, Amazonas, Brazil. Kew Bulletin 66: 463470.

Thiers, B. (constantly updated). Index Herbariorum: A global directory of public herbaria and associated staff. New York Botanical Gardens' Virtual Herbarium. <http://sweetgun. nybg.org/ih/> Online version. Date of download 9 March 2012.

Valente, T.P. \& R.R.B. Negrelle (2011). Harvesting of cipópreto (roots of Philodendron corcovadense Kunth) in the South of Brazil. Forests, Trees and Livelihoods 20: 211212. 